\title{
PENERAPAN STRATEGI PEMBELAJARAN AKTIF TIPE TRUE OR FALSE UNTUK MENINGKATKAN HASIL BELAJAR PESERTA DIDIK PADA POKOK BAHASAN TEKS EKSPOSISI KELAS X MIPA 1 SMA NEGERI 2 PEKANBARU
}

\author{
(Applying True or False Active Learning Strategies to Increase Students 'Learning Outcomes \\ in the Topic of Text Exposition of Class X MIPA 1 SMA Negeri 2 Pekanbaru)
}

\section{Oleh: Nurmaini*)}

*) Guru Bahasa Indonesia SMA Negeri 2 Pekanbaru

\begin{abstract}
Learning is a system that aims to help the learning process of students, which contains a series of events that are designed, arranged in such a way as to influence and support the learning process of students (Firdaus, 2012). According to Nasution (2000) the learning process is an interaction / process of communication between the teacher and students and between students and students. Intertwined communication should be reciprocal communication created in such a way, so that the message conveyed in the form of the subject matter will be effective and efficient. Students as the subject of learning must play an active role in learning. the activeness of students is assessed from their role in learning, such as asking questions, answering questions, giving responses and others. In addition, the activeness of students is a form of independent learning, namely students trying to learn everything about their own will and ability / business, so that in this case the teacher only acts as a mentor, motivator and facilitator. Therefore, the teacher needs to create an atmosphere of learning that can foster an attitude of collaboration between students and other students. The main problem in learning in formal education (school) today is the low absorption of students. The learning process to this day is still dominated by teachers and does not provide access for students to develop independently through discovery in the process of thinking. According to Dimyati and Mudjiono (2002) the dominance of teachers in the learning process causes students to be passively involved, students are more waiting for the presentation of the teacher rather than looking for and finding their own knowledge, skills and attitudes they need during the learning process. Therefore, it is necessary to apply new learning strategies that can make students actively participate in learning. One active learning strategy developed by Silberman (2011) is true or false active learning strategies. The learning steps in the true or false active learning strategy will activate students from the beginning of learning which will stimulate students to think and motivate students to play an active role in learning activities so that the teacher does not dominate the learning process. This strategy is marked by the teacher making statements that are in accordance with the subject matter, half right and the other half wrong. Then students discuss in their groups to state whether the statement is true or false. By discussing students can exchange opinions. According to Silberman (2011) by listening to various opinions, students will be challenged to think. our brain will do a better learning process if we discuss information with other people. When the learning process is passive, the brain cannot store information properly. In answering questions, students are required to give reasons why they answer correctly and why they answer wrongly. This is so that students do not guess when answering and will make students better understand the material. Then the results of the group discussion will be presented in front of the class, students are given the opportunity to ask questions, answer questions and respond or give opinions. This will activate students more in learning and can train students' courage. According to Silberman (2011), learning activities carried out with the activities of students themselves will cause a knowledge to be more meaningful and can last a long time in memory of students so that the learning outcomes achieved will be better. Based on the results of the study obtained values from the first and second cycles in a row - according (77.33\%), and $(80.00 \%)$.
\end{abstract}


Kata Kunci : Active Learning Strategy, true or false 


\section{PENDAHULUAN}

Pembelajaran adalah suatu sistem yang bertujuan untuk membantu proses belajar peserta didik, yang berisi serangkaian peristiwa yang dirancang, disusun sedemikian rupa untuk mempengaruhi dan mendukung terjadinya proses belajar peserta didik (Firdaus, 2012). Menurut Nasution (2000) proses pembelajaran merupakan interaksi/proses komunikasi antara guru dengan peserta didik dan antara peserta didik dengan peserta didik. Komunikasi yang terjalin hendaknya merupakan komunikasi timbal balik yang diciptakan sedemikian rupa, sehingga pesan yang disampaikan dalam bentuk materi pelajaran berlangsung efektif dan efisien. Peserta didik sebagai subjek belajar harus berperan aktif dalam pembelajaran. Keaktifan peserta didik dinilai dari peranannya dalam pembelajaran, seperti bertanya, menjawab pertanyaan, member tanggapan dan lainlain. Disamping itu, keaktifan peserta didik merupakan bentuk pembelajaran mandiri, yaitu peserta didik berusaha mempelajari segala sesuatu atas kehendak dan kemampuannya/usahanya sendiri, sehingga dalam hal ini guru hanya berperan sebagai pembimbing, motivator dan fasilitator. Oleh karena itu, guru perlu menciptakan suasana belajar yang dapat menumbuhkan sikap bekerjasama antara peserta didik satu dengan peserta didik lainnya. Masalah utama dalam pembelajaran pada pendidikan formal (sekolah) dewasa ini adalah masih rendahnya daya serap peserta didik. Proses pembelajaran hingga dewasa ini masih didominasi oleh guru dan tidak memberikan akses bagi peserta didik untuk berkembang secara mandiri melalui penemuan dalam proses berfikirnya. Menurut Dimyati dan Mudjiono (2002) dominasi guru dalam proses pembelajaran menyebabkan peserta didik terlibat secara pasif, peserta didik lebih banyak menunggu sajian dari guru dari pada mencari dan menemukan sendiri pengetahuan, keterampilan dan sikap yang mereka butuhkan saat proses pembelajaran. Oleh karena itu, diperlukan adanya penerapan strategi pembelajaran baru yang dapat membuat peserta didik ikut aktif dalam pembelajaran. Salah satu strategi pembelajaran aktif yang dikembangkan oleh Silberman (2011) adalah strategi pembelajaran aktif tipe true or false. Langkah-langkah pembelajaran dalam strategi pembelajaran aktif tipe true or false akan mengaktifkan peserta didik sejak awal pembelajaran yang akan merangsang peserta didik untuk berfikir dan memotivasi peserta didik untuk berperan aktif dalam aktifitas belajar sehingga guru tidak terlalu mendominasi proses pembelajaran. Strategi ini ditandai dengan guru membuat pernyataanpernyataan yang sesuai dengan materi pelajaran, separuh benar dan separuhnya lagi salah. Kemudian peserta didik berdiskusi dalam kelompoknya untuk menyatakan apakah pernyataan tersebut benar atau salah. Dengan berdiskusi peserta didik dapat saling bertukar pendapat. Menurut Silberman (2011) dengan mendengarkan beragam pendapat, peserta didik akan tertantang untuk berfikir. Otak kita akan melakukan proses belajar yang lebih baik jika kita membahas informasi dengan orang lain. Ketika proses belajar pasif, maka otak tidak dapat menyimpan informasi dengan baik. Dalam menjawab soal pernyataan, peserta didik diharuskan untuk memberikan alas an mengapa menjawab benar dan mengapa pula menjawab salah. Hal ini bertujuan agar peserta didik tidak asal tebak dalam menjawab dan akan membuat peserta didik lebih memahami materi. Kemudian hasil diskusi kelompok akan dipresentasikan di depan kelas, peserta didik diberikan kesempatan bertanya, menjawab pertanyaan dan menanggapi atau memberikan pendapat. Hal ini akan lebih mengaktifkan peserta didik dalam pembelajaran dan dapat melatih keberanian peserta didik. Menurut Silberman (2011), kegiatan belajar yang dilakukan dengan aktivitas peserta didik 
sendiri akan menyebabkan suatu pengetahuan lebih bermakna dan dapat bertahan lama diingatan peserta didik sehingga hasil belajar yang dicapai akan lebih baik.

\section{METODE PENELITIAN}

Penelitian ini merupakan penelitian tindakan (action research), karena penelitian ini dilakukan untuk memecahkan masalah pelajaran di kelas. Penelitian ini juga termasuk penelitian deskriptif, sebab menggambarkan bagaimana suatu tekhnik pembelajaran diterapkan dan bagaimana hasil yang diinginkan dapai dicapai. Tempat penelitian adalah tempat yang digunakan dalam melakukan penelitian untuk memperoleh data yang diinginkan. Penelitian ini bertempat di SMA Negeri 2 Pekanbaru. Waktu penelitian adalah waktu berlangsungnya penelitian atau saat penelitian ini berlangsung. Penelitian ini dilaksanakan pada awal bulan Agustus sampai pertengahan bulan September 2016. Subyek penelitian adalah peserta didik kelas X MIPA 1 tahun 2016 pada pokok bahasan Teks Eksposisi.

\section{Tekhnik Analisa Data}

Untuk mengetahui kefektivan suatu metode dalam kegiatan pembelajaran perlu diadakan analisa data. Pada penelitian ini menggunakan tekhnik analisa deskriptif kuantitatif, yaitu suatu metode penelitian yang bersifat menggambarkan kenyataan atau fakta sesuai dengan data yang diperoleh dengan tujuan untuk mengetahui hasil belajar yang dicapai siswa juga untuk memperoleh respon siswa terhadap kegiatan pembelajaran serta aktivitas siswa selama proses pembelajaran. Untuk menganalisis tingkat keberhasilan atau presentase keberhasilan siswa setelah proses belajar mengajar setiap putarannya dilakukan dengan cara memberikan evaluasi berupa soal tes tertulis pada akhir putaran.

Analisis ini dihitung dengan menggunakan statistik sederhana yaiu :
1. Untuk menilai ulangan atau tes formatif

Peneliti melakukan penjumlahan nilai yang diperoleh siswa yang selanjutnya dibagi dengan jumlah siswa yang ada di kelas tersebut sehingga diperoleh rata rata tes formatif dapat dirumuskan.

$$
\chi=\frac{\sum X}{\sum N}
$$

Dengan $: \chi=$ nilai rata - rata

$$
\begin{aligned}
& : \sum X=\text { jumlah semua nilai } \\
& \text { siswa } \\
& : \sum N=\text { jumlah peserta didik }
\end{aligned}
$$

2. Untuk ketuntasan belajar

Ada dua kategori ketuntasan belajar yaitu secara perorangan dan secara klasikal. Berdasarkan petunjuk pelaksanaan belajar mengajar, seorang siswa telah tuntas belajar bila telah mencapai skor $75 \%$ atau nilai 75 . Dan kelas tersebut tuntas belajar bila di kelas tersebut terdapat $75 \%$ yang telah mencapai daya serap lebih dari atau sama dengan $80 \%$. Untuk menghitung presentase ketuntasan belajar digunakan rumus sebagai berikut :

$$
\begin{gathered}
\mathrm{P}= \\
\frac{\sum \text { Peserta Didik yang tuntas belajar }}{\sum \text { Peserta Didik }} \\
100 \%
\end{gathered}
$$

\section{HASIL DAN PEMBAHASAN}

Penelitian tindakan kelas dilaksanakan di kelas $\mathrm{X}$ MIPA 1 SMA Negeri 2 Pekanbaru pada semester ganjil tahun ajaran 2016/2017 yang berjumlah 30 orang peserta didik, terdiri dari 10 peserta didik laki-laki dan 20 peserta didik perempuan. Penelitian dilaksanakan Peneliti Dra. $\mathrm{Hj}$. Nurmaini dan Dra. Murniati. Dimana Dra. Hj. Nurmaini sebagai pelaksana tindakan sedangkan Dra. Murniati sebagai observer. Penelitian dilakukan sebanyak 2 siklus, setiap siklus terdiri dari 2 kali pertemuan dengan alokasi waktu setiap pertemuan adalah 2 x 45 menit dan diamati oleh observer yang melakukan observasi terhadap aktivitas peserta didik dan guru selama berlangsungnya proses pembelajaran dengan menggunakan lembar observasi.Penelitian bertujuan 
untuk meningkatkanhasil belajar bahasa indonesia peserta didik dengan menerapkan strategi pembelajaran aktif tipe true or false pada pokok bahasan teks eksposisi. Data yang diperoleh dalam penelitian ini adalah hasil pengamatan aktivitas peserta didik dan guru setiap kali pertemuan dan nilai posttest yang diberikan setiap akhir siklus dalam bentuk essay dengan alokasi waktu 2 x 45 menit. Data yang diperoleh dalam penelitian ini merupakan data hasil penerapan strategi pembelajaran aktif tipe true or false terhadap peserta didik selama proses pembelajaran berlangsung. Pelaksanaan kegiatan belajar mengajar untuk siklus 1 dilaksanakan pada tanggal 04 Agustus 2016 di kelas X MIPA 1 dengan jumlah peserta didik 30 orang. Dalam hal ini peneliti bertindak sebagai guru. Adapun proses belajar mengajar mengacu pada rencana pelajaran yang telah dipersiapkan. Pengamatan (observasi) dilaksanakan bersamaan dengan pelaksanaan belajar mengajar. Pada akhir proses belajar mengajar diberi tes formatif 1 dengan tujuan untuk mengetahui tingkat keberhasilan peserta didik dalam proses belajar mengajar yang telah dilakukan. dijelaskan bahwa dengan menerapkan strategi pembelajaran aktif tipe true or false diperoleh nilai rata - rata hasil belajar peserta didik adalah 77,66 dan ketuntasan belajar mencapai $73.33 \%$ atau ada 22 peserta didik dari 30 peserta didik yang sudah tuntas belajar. hasil tersebut menunjukkan bahwa pada siklus pertama secara klasikal peserta didik sudah tuntas belajar, karena peserta didik yang memperoleh nilai $\geq 75$ hanya sebesar 77,66. Ini lebih kecil dari presentase ketuntasan yang dikehendaki yaitu sebesar 75\%. Pelaksanaan kegiatan belajar mengajar untuk siklus II dilaksanakan pada tanggal 19 Agustus 2016 di kelas X MIPA 1 dengan jumlah peserta didik sebanyak 30 orang. Dalam hal ini peneliti bertindak sebagai guru. Adapun proses belajar mengajar mengacu pada rencana pembelajaran dengan memperhatikan revisi pada siklus 1, sehingga kesalahan atau kekurangan pada siklus 1 tidak terulang lagi pada siklus II. Pengamatan (observasi) dilaksanakan bersamaan dengan pelaksanaan belajar mengajar. diperoleh nilai rata - rata hasil belajar peserta didik adalah 84.63 dan ketuntasan belajar mencapai $100 \%$ atau ada 30 orang peserta didik dari 30 peserta didik yang sudah tuntas belajar. hasil ini menunjukkan bahwa pada siklus II ini ketuntasan belajar secara klasikal telah mengalami peningkatan sedikit lebih baik dari siklus I. Adanyan peningkatan hasil belajar peserta didik ini karena peserta didik sudah mulai terbiasa dengan strategi pembelajaran aktif tipe true or false yang diterapkan oleh guru. Disamping itu kemampuan guru dalam pengelolaan proses belajar mengajar semakin mantap sehingga hasilnya pun hasil belajar peserta didik semakin meningkat

\section{Pembahasan}

Peningkatan hasil belajar peserta didik dengan penerapan strategi pembelajaran aktif tipe true or false terjadi karena peserta didik terlibat aktif dalam proses pembelajaran, yaitu dimulai ketika peserta didik dalam kelompoknya berdiskusi dalam merumuskan alasan yang tepat untuk setiap pernyataan yang dianggap benar atau salah, serta mengemukakan pendapat dan menanggapi pertanyaan ketika presentasi. Silberman (2011) mengatakan bahwa pembelajaran aktif meliputi berbagai cara untuk membuat peserta didik aktif sejak awal melalui aktivitas-aktivitas yang membangun kerja kelompok dan dalam waktu singkat membuat mereka berfikir tentang materi pelajaran. Pembelajaran aktif sangat diperlukan oleh peserta didik untuk mendapatkan hasil belajar yang maksimum. Ketika peserta didik pasif atau hanya menerima dari pengajar, ada kecenderungan untuk cepat melupakan apa yang telah diberikan. Ketika berdiskusi peserta didik diberi keleluasaan tentang bagaimana cara menyelesaikan tugas 
dalam kelompoknya, selain dapat mengarahkan peserta didik untuk lebih mudah bertanya dan mengeluarkan pendapat, strategi ini dapat menumbuhkan rasa tanggung jawab peserta didik untuk menyelesaikan tugas. Firdaus (2012) mengatakan bahwa pentingnya tujuan kelompok dan tanggung jawab individu merupakan motivasi bagi peserta didik untuk membantu satu sama lain dan saling mendorong untuk melakukan usaha yang maksimal. Salah satu contoh pernyataan pada penerapan strategi pembelajaran aktif tipe true or falseyang didiskusikan oleh peserta didik pada pertemuan ketiga yaitu "kalimat nominal". Setiap peserta didik berdiskusi dan bekerjasama dalam kelompoknya masing-masing dalam mencari informasi dari sumber belajar yang ada untuk menentukan pernyataan tersebut benar atau salah disertai dengan alasannya. Penjabaran alasan merupakan aktivitas yang dapat mengembangkan berfikir kritis. Ketika berfikir kritis, peserta didik akan berusaha menganalisa berdasarkan fakta-fakta yang telah mereka dapatkan. Menganalisa dan berfikir kritis merupakan salah satu ciri aktivitas mental dalam proses pembelajaran (Sardiman, 2011). Merumuskan alasan yang tepat, maka peserta didik telah mampu mengkonstruksi pengetahuannya sendiri. Budiningsih (2005) mengemukakan bahwa jika peserta didik mampu mengkonstruksi pengetahuannya sendiri, maka pengetahuan dan pemahaman peserta didik tersebut akan meningkat. Hasil diskusi dari tiap kelompok akan dipresentasikan di depan kelas dengan cara diundi baik kelompok maupun perwakilan kelompok yang akan mempresentasikan hasil diskusinya. Hal ini bertujuan untuk mencegah tugas hanya dilakukan oleh beberapa orang saja. Selain itu akan mendorong peserta didik untuk lebih menguasai materi untuk mewakili kelompoknya dalam mempresentasikan hasil diskusi. Hal ini sesuai dengan yang dikemukakan Silberman (2011) bahwa salah satu cara agar peserta didik belajar aktif dan produktif dalam kelompok adalah dengan penugasan secara acak. Saat presentasi berlangsung, peserta didik dari kelompok lain diberikan kesempatan untuk bertanya, mengeluarkan pendapat atau menanggapi hasil diskusi dari kelompok penyaji. Keterlibatan peserta didik dalam bertanya, mengeluarkan pendapat ataupun menanggapi, memperlihatkan peran aktif peserta didik dalam mengikuti proses pembelajaran. Hal ini dapat menimbulkan motivasi dalam diri peserta didik dalam mengikuti proses pembelajaran di kelas. Menurut Firdaus (2012), dalam belajar, sangat diperlukan adanya motivasi. Makin tepat motivasi yang diberikan, akan makin berhasil pula kegiatan pembelajaran. jadi motivasi akan senantiasa menentukan intensitas usaha belajar bagi para peserta didik, sehingga hasil belajar yang diraih akan lebih baik. Ada beberapa kendala yang dihadapi dalam penerapan strategi pembelajaran aktif tipe true or false pada pokok bahasan teks eskposisi diantaranya yaitu pada pertemuan pertama, masih ada kelompok yang belum mengerti tentang cara penerapan strategi pembelajaran aktif tipe true or false pada pokok teks eksposisi. Untuk mengatasi masalah tersebut, peneliti menjelaskan kembali tentang cara penerapan strategi pembelajaran aktif tipe true or false pada pokok bahasan teks eksposisi dan memberikan beberapa contoh pernyataan beserta alasannya. Selain itu, masih banyak peserta didik yang belum terlibat aktif berdiskusi dalam kelompoknya. Hal ini terjadi karena masih kurangnya rasa tanggung jawab mereka terhadap tugas yang diberikan. Untuk mengatasi masalah tersebut, guru memberitahukan kepada seluruh peserta didik bahwa hasil diskusi akan dipresentasikan di depan kelas dengan cara diundi, baik kelompok yang tampil maupun peserta didik sebagai perwakilan kelompoknya. Hal ini bertujuan untuk menanamkan rasa tanggung jawab kepada masing-masing peserta didik untuk menyelesaikan tugas dengan cara bekerjasama. Kelompok akan 
memastikan semua anggotanya telah mempelajari materi, karena keberhasilan kelompok bergantung pada semua anggotanya. Oleh karena itu anggota kelompok akan termotivasi untuk saling mengajarkan (Firdaus, 2012). Pada pertemuan terakhir, kelompok yang terbaik akan diumumkan di depan kelas. Hal ini bertujuan untuk meningkatkan motivasi peserta didik dalam belajar. Setiap peserta didik dalam kelompoknya akan lebih aktif dan lebih serius dalam menyelesaikan tugas yang diberikan guru. Hal ini sesuai dengan yang dikemukakan oleh Uno (2008) bahwa membuat suasana persaingan yang sehat diantara peserta didik menimbulkan upaya belajar yang sungguh-sungguh.

\section{KESIMPULAN}

Berdasarkan hasil penelitian dan pembahasan dapat disimpulkan sebagai berikut :

a) Penerapan strategi pembelajaran aktif tipe true or false dapat meningkatkan hasil belajar peserta didik dengan persentase pada siklus I sebesar $77,63 \%$, dan siklus II sebesar $84.63 \%$.

\section{DAFTAR PUSTAKA}

Arikunto, S., 2005, Dasar-dasar Evaluasi Pendidikan, Bumi Aksara, Jakarta.

Budiningsih, A.C., 2005, Belajar dan Pembelajaran, Asdi Mahasatya, Jakarta.

Depdiknas, 2006, Petunjuk Teknis Pengembangan Silabus dan Contoh/Model Silabus SMA/MA, BSNP, Jakarta.

Dimyati dan Mujiono, 2002, Belajar dan pembelajaran, Departemen Pendidikan dan Kebudayaan, Jakarta.

Djamarah, 2006, Strategi Belajar Mengajar,Rineka Cipta, Jakarta.

Firdaus, T., 2012, Pembelajaran Aktif, Elmatera, Yogyakarta.

Hartono, 2011, PAIKEM, Zanafa, Pekanbaru.

Ibrahim, M., 2000, Pembelajaran Kooperatif, University Press, Universitas Negeri Surabaya.

Nasution,S., 2000, Belajar dan Mengajar,Bumi aksara, Bandung.

Nazir, 2005, Metode Penelitian, Ghalia Indonesia, Jakarta.

Sanjaya, W., 2008, Strategi Pembelajaran Berorientasi Standar Proses Pendidikan, Kencana, Jakarta.

Sardiman, 2011, Interaksi dan Motivasi Belajar Mengajar, Raja
GrafindoPersada, 
